\title{
Gallbladder Perforation: A Prospective Study of Its Divergent Appearance and Management
}

\author{
Gaurav Patel ${ }^{1}$, Atul Jain ${ }^{2}$, Ram B Kumar ${ }^{3}$, Nirbhay Singh ${ }^{4}$, Tanweer Karim ${ }^{5}$, Raghav Mishra ${ }^{6}$
}

\begin{abstract}
Introduction: Gallstone disease is one of the most common surgical diseases. Complications associated with cholelithiasis is not uncommon, but gallbladder perforation is a rare complication of acute cholecystitis with cholelithiasis. This gallbladder perforation may present in different ways like free perforation inside peritoneal cavity causing generalized peritonitis, localized collection around gallbladder fossa after perforation and in chronic cases cholecystoenteric fistula. Here we present our experience of this condition with a review of literature for a different presentation of this condition.

Materials and methods: This study was done for 2 years, and patients who were diagnosed with gallbladder perforation either preoperatively or intraoperatively were included.

Results: There was a total of 16 patient included in the study during this period which were either diagnosed preoperatively or intraoperatively of gallbladder perforation (GBP).

Conclusion: GBP, though a rare complication of cholecystitis with high morbidity and mortality, has no specific pathognomic feature and is often misdiagnosed or late diagnosed. Nowadays most cases can be managed with improved diagnostic means and therapeutic modalities (endoscopic, laparoscopic, endostaplers).
\end{abstract}

Keywords: Cholecystectomy, Cholecystitis, Fistula, Gallbladder perforation.

Euroasian Journal of Hepato-Gastroenterology (2019): 10.5005/jp-journals-10018-1289

\section{INTRODUCTION}

G allbladder perforation (GBP) is a rare yet potentially fatal J condition occurring as a complication of cholecystitis (calculous or acalculous). The clinical presentation of GBP may not be different from uncomplicated acute cholecystitis, or at times its presentation may perplex the clinician. The clinical features of GBP may vary from that of peritonitis to acute cholecystitis. The mortality rate of GBP is reported to be $12-16 \%{ }^{1}$ Acute cholecystitis, calculus, or acalculous, can lead to GBP in $6-12 \%$ of cases. ${ }^{2,3}$ There are many classifications proposed for GBP, but Niemeier classification is most commonly used. In 1934, he categorized GBP perforation in 3 types, type 1 (acute)-it manifests as generalized peritonitis, type 2 (subacute)-localization of fluid at the site of perforation with pericholecystic abscess and type 3 (chronic) -internal (bilio enteric) or external (cholecysto cutaneous) fistula. ${ }^{4}$

Here we present our experience of this condition with variable presentation and poorly understood etiology, which is often diagnosed late resulting in high morbidity and mortality rate; dealt by us over a period of 2 years in our institute. The different clinical presentations and its management along with a brief review of the literature available are done in this study.

\section{Materials and methods}

This study was done over a period of 2 years and patients who were diagnosed with gallbladder perforation either preoperatively or intraoperatively were included. The clinical presentation, demographic profile, investigations, and management done was recorded. The different possible etiological factors associated with GBP are also discussed.

\section{Results}

There was a total of 16 patient included in the study during this period which were either diagnosed preoperatively or
${ }^{1-6}$ Department of Surgery, ESI Posgraduate Institute of Medical Science and Research and Hospital, New Delhi, India

Corresponding Author: Atul Jain, Department of Surgery, ESI Posgraduate Institute of Medical Science and Research and Hospital, New Delhi, India, e-mail: docatuljain@gmail.com

How to cite this article: Patel G, Jain A, et al. Gallbladder Perforation: A Prospective Study of Its Divergent Appearance and Management. Euroasian J Hepatogastroenterol 2019;9(1):14-19.

Source of support: Nil

Conflict of interest: None

intraoperatively of GBP as per the Neimer classification (Table 1). Total 11 patients were diagnosed with GB perforation on the basis of clinical and radiological evaluation, whereas five patients were diagnosed intraoperatively of the pathology. Seven patients had acute cholecystitis and nine had chronic cholecystitis feature on histopathological examination. Two patients had acute acalculous cholecystitis. There was male predominance over the female (10:6 ratio) and type 2 (7) perforation was seen more as compared to type 1 (5) and type 3 (4) (Table 2). The youngest patient reported in our series was of age 17 years and the oldest was of age 80 years. Mean age of patients was 45.56 years (Table 3 ). The clinical presentation in our series was with general symptoms like pain abdomen, fever, vomiting. Blood investigations showed leucocytosis and raised ALP. There were some atypical presentations like 2 patients presenting with anterior abdominal wall abscess.

The diagnosis was reached with the help of radiological investigation ultrasound abdomen and CT scan abdomen (Figs 1 and 2). Whenever USG was not conclusive or was partial in favor of GBP; CT abdomen was done.USG was done in all 16 cases, out of which it confirmed perforation only in six cases. CT abdomen was done in eight cases where it confirmed the GBP. The comorbidity

(O) The Author(s). 2019 Open Access This article is distributed under the terms of the Creative Commons Attribution 4.0 International License (https://creativecommons. org/licenses/by-nc/4.0/), which permits unrestricted use, distribution, and non-commercial reproduction in any medium, provided you give appropriate credit to the original author(s) and the source, provide a link to the Creative Commons license, and indicate if changes were made. The Creative Commons Public Domain Dedication waiver (http://creativecommons.org/publicdomain/zero/1.0/) applies to the data made available in this article, unless otherwise stated. 
Table 1: Total patients involved in the study with presentation, perforation type and management done

\begin{tabular}{|c|c|c|c|c|c|c|c|}
\hline $\begin{array}{l}\text { S. } \\
\text { No. }\end{array}$ & Age & Sex & Presentation & Comorbidities & Diagnosis & $\begin{array}{l}\text { Perforation } \\
\text { type }\end{array}$ & Treatment \\
\hline 1. & 65 & M & Abdominal wall abscess & DM & $\begin{array}{l}\text { GBP with Ant. } \\
\text { abdominal wall } \\
\text { abscess }\end{array}$ & Type 3 & Open cholecystectomy \\
\hline 2. & 55 & M & Abdominal wall abscess & DM, HTN & $\begin{array}{l}\text { GBP with Ant. } \\
\text { abdominal wall } \\
\text { abscess }\end{array}$ & Type 3 & Open cholecystectomy \\
\hline 3. & 65 & $\mathrm{~F}$ & Pain abdomen, fever, vomiting & ----------- & $\begin{array}{l}\text { Acalculous } \\
\text { cholecystitis with } \\
\text { GBP }\end{array}$ & Type 1 & $\begin{array}{l}\text { Exploratory } \\
\text { laparotomy with } \\
\text { cholecytectomy }\end{array}$ \\
\hline 4. & 49 & M & Pain abdomen, fever, vomiting & ----------- & $\begin{array}{l}\text { Calculous } \\
\text { cholecystitis } \\
\text { with sealed GB } \\
\text { perforation }\end{array}$ & Type 2 & $\begin{array}{l}\text { Elective open } \\
\text { cholecystectomy }\end{array}$ \\
\hline 5. & 47 & $\mathrm{~F}$ & Pain abdomen, fever, vomiting & ------ & $\begin{array}{l}\text { Calculous } \\
\text { cholecystitis } \\
\text { with sealed GB } \\
\text { perforation }\end{array}$ & Type 2 & $\begin{array}{l}\text { Pigtail drainage } \\
\text { followed by elective } \\
\text { open cholecystectomy }\end{array}$ \\
\hline 6. & 37 & M & Pain abdomen, fever, vomiting & $\begin{array}{l}\text { Typhoid fever } \\
\text { in recent past }\end{array}$ & $\begin{array}{l}\text { Calculous } \\
\text { cholecystitis } \\
\text { with sealed GB } \\
\text { perforation }\end{array}$ & Type 2 & $\begin{array}{l}\text { Antibiotics followed } \\
\text { by elective open } \\
\text { cholecystectomy }\end{array}$ \\
\hline 7. & 45 & M & $\begin{array}{l}\text { H/o pain abdomen and fever } \\
\text { subsided on conservative } \\
\text { treatment }\end{array}$ & -------- & $\begin{array}{l}\text { Calculous } \\
\text { cholecystitis } \\
\text { with sealed GB } \\
\text { perforation }\end{array}$ & Type 2 & $\begin{array}{l}\text { Laparoscopic } \\
\text { cholecystectomy }\end{array}$ \\
\hline 8. & 25 & $\mathrm{~F}$ & $\begin{array}{l}\text { H/o pain abdomen and fever } \\
2 \text { months back subsided on } \\
\text { conservative treatment }\end{array}$ & -------- & $\begin{array}{l}\text { Calculous } \\
\text { cholecystitis } \\
\text { with sealed GB } \\
\text { perforation }\end{array}$ & Type 2 & $\begin{array}{l}\text { Laparoscopic } \\
\text { cholecystectomy }\end{array}$ \\
\hline 9. & 80 & M & Pain, fever, constipation & -------- & $\begin{array}{l}\text { Acute acalculous } \\
\text { cholecystitis with GB } \\
\text { perforation }\end{array}$ & Type 2 & Open cholecystectomy \\
\hline 10. & 70 & $\mathrm{~F}$ & Pain abdomen, fever, vomiting & DM & $\begin{array}{l}\text { Acute calculus } \\
\text { cholecystitis with GB } \\
\text { perforation }\end{array}$ & Type 2 & Open cholecystectomy \\
\hline 11. & 31 & $\mathrm{~F}$ & Pain abdomen & --------- & $\begin{array}{l}\text { Chronic calculus } \\
\text { cholecystitis with } \\
\text { cholecystogastric } \\
\text { fistula }\end{array}$ & Type 3 & $\begin{array}{l}\text { Laparoscopic } \\
\text { cholecystectomy with } \\
\text { fistula repair }\end{array}$ \\
\hline 12. & 24 & $\mathrm{~F}$ & Pain abdomen & ------------- & $\begin{array}{l}\text { Chronic calculus } \\
\text { cholecystitis with } \\
\text { cholecystogastric } \\
\text { fistula }\end{array}$ & Type 3 & $\begin{array}{l}\text { Laparoscopic } \\
\text { cholecystectomy with } \\
\text { fistula repair }\end{array}$ \\
\hline 13. & 17 & M & Pain abdomen, fever, vomiting & -------------- & $\begin{array}{l}\text { Acute calculus } \\
\text { cholecystitis with GB } \\
\text { perforation }\end{array}$ & Type 1 & $\begin{array}{l}\text { Exploratory } \\
\text { laparotomy with } \\
\text { cholecystectomy }\end{array}$ \\
\hline 14. & 40 & M & Pain abdomen, fever & -------------- & $\begin{array}{l}\text { Acute calculus } \\
\text { cholecystitis with GB } \\
\text { perforation }\end{array}$ & Type 1 & $\begin{array}{l}\text { Exploratory } \\
\text { laparotomy with } \\
\text { cholecystectomy }\end{array}$ \\
\hline 15. & 56 & M & Pain abdomen, fever & DM & $\begin{array}{l}\text { Acute calculus } \\
\text { cholecystitis with GB } \\
\text { perforation }\end{array}$ & Type 1 & $\begin{array}{l}\text { Exploratory } \\
\text { laparotomy with } \\
\text { cholecystectomy }\end{array}$ \\
\hline 16. & 23 & M & Pain abdomen, fever & ------------ & $\begin{array}{l}\text { Acute calculus } \\
\text { cholecystitis with GB } \\
\text { perforation }\end{array}$ & Type 1 & $\begin{array}{l}\text { Exploratory } \\
\text { laparotomy with } \\
\text { cholecystectomy }\end{array}$ \\
\hline
\end{tabular}


Table 2: Total number of patients in study with distribution according to gender and type of perforation

\begin{tabular}{llll}
\hline \multirow{2}{*}{$\begin{array}{l}\text { Type of } \\
\text { perforation }\end{array}$} & \multicolumn{3}{c}{ No of patients } \\
\cline { 2 - 3 } & Male & Female & Total \\
\hline Type 1 & 4 & 1 & $5(31.3 \%)$ \\
Type 2 & 4 & 3 & $7(43.7 \%)$ \\
Type 3 & 2 & 2 & $4(25 \%)$ \\
\hline Total & 10 & 6 & 16 \\
\hline
\end{tabular}

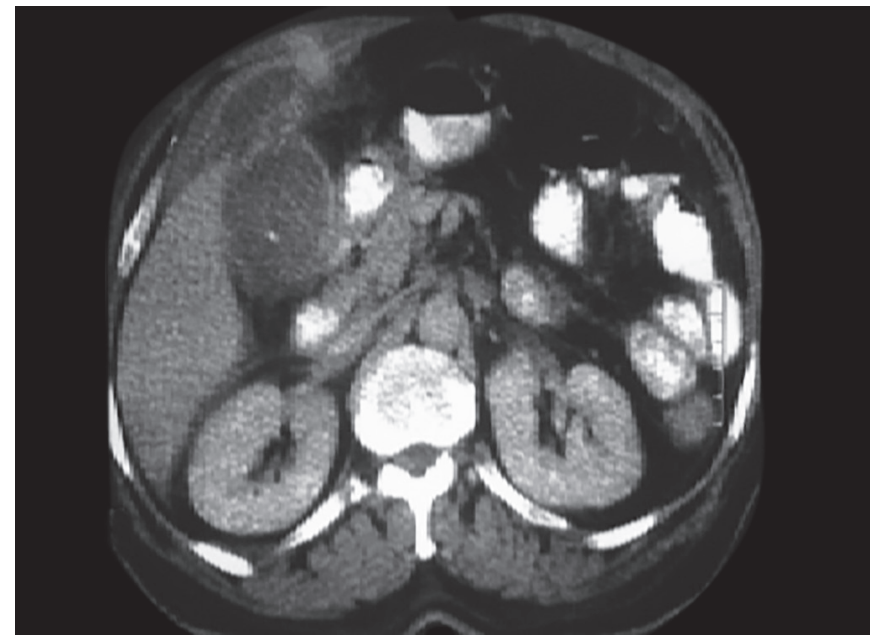

Fig. 1: CT abdomen showing perforation in the gallbladder and cholecystocutaneous fistula

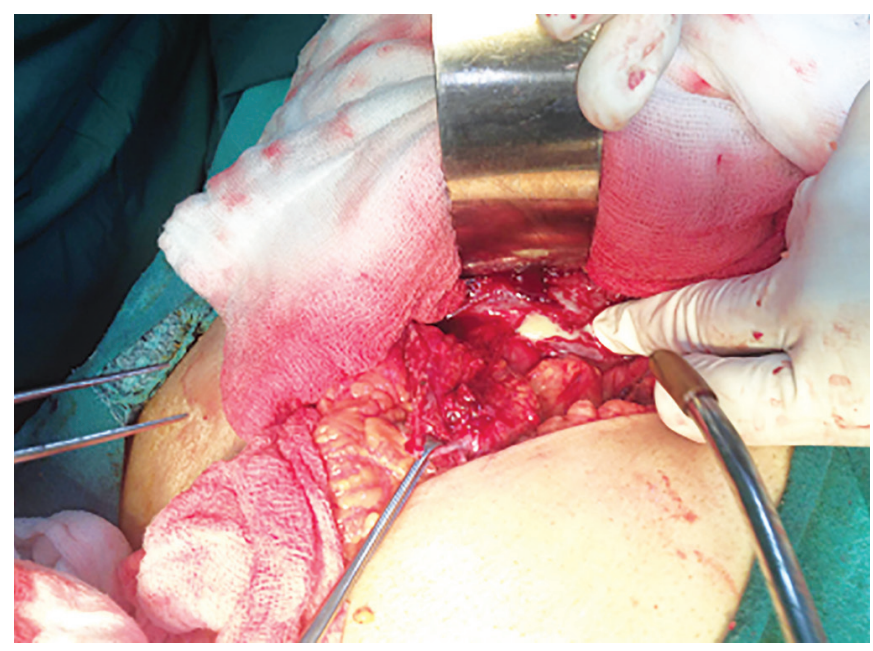

Fig. 3: Intraoperative photo of open cholecystectomy showing pus draining from the gallbladder after draining and opening anterior abdominal wall abscess

in our series was diabetes mellitus (DM) in 4 cases and HTN in two cases. There was a history of typhoid fever in one patient a few days before the presentation with GBP.

The surgery for six diagnosed cases of GB perforation was taken on emergency basis whereas in the rest cases (10) either the diagnosis was intraoperative (5) or the surgery was delayed, and the patient was initially managed by antibiotic and other supportive treatment with or without pigtail drainage of collection. Four patients underwent laparoscopic cholecystectomy and seven patients had open cholecystectomy (Figs 3 and 4). Five patients
Table 3: Age-wise distribution of patients in our study

\begin{tabular}{llll}
\hline Age & Male & Female & Total \\
\hline$\leq 20$ & 1 & - & 1 \\
$21-30$ & 1 & 2 & 3 \\
$31-40$ & 2 & 1 & 3 \\
$41-50$ & 2 & 1 & 3 \\
$51-60$ & 2 & - & 2 \\
$61-70$ & 1 & 2 & 3 \\
$71-80$ & 1 & - & 1 \\
\hline Total & 10 & 6 & 16 \\
\hline
\end{tabular}

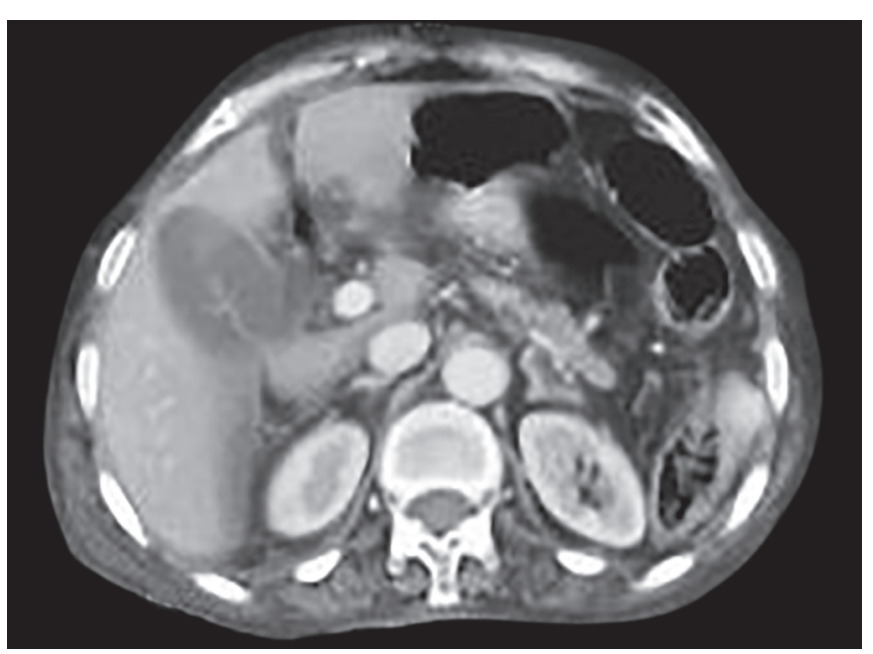

Fig. 2: CT showing gallbladder distended with $10 \mathrm{~mm}$ size defect posterosuperiorly and pericholecystic collection

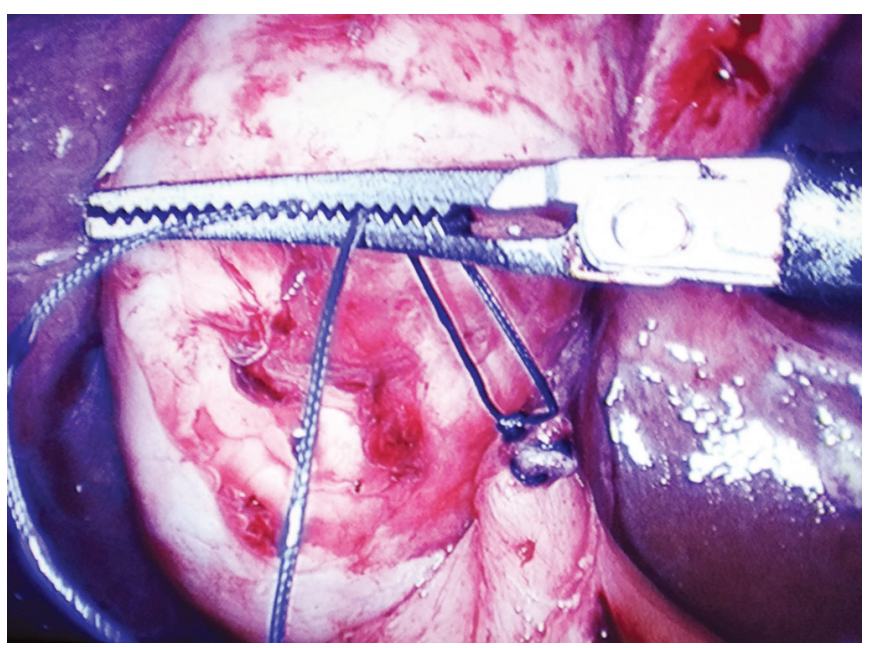

Fig. 4: Laparoscopic repair of cholecystogastric fistula-type 3 perforation

underwent midline laparotomy with peritoneal lavage and drain placement.

The mortality in our series was $6.25 \%$ ( 1 out of 16 patients). The type $1 \mathrm{GBP}$ was associated with the mortality and the patient succumbed to the sepsis. The average length of hospital stay was 15 days ranging from $5-25$ days.

Twenty-five studies were reviewed which reported for GBP (Table 4). ${ }^{5-29}$ The comparison of these studies with our series is done in the discussion. 
Table 4: Summary of various studies reported with their different presentation and type of perforation

\begin{tabular}{|c|c|c|c|c|c|c|c|c|}
\hline $\begin{array}{l}\text { S. } \\
\text { No }\end{array}$ & Study & $\begin{array}{l}\text { No. of } \\
\text { cases }\end{array}$ & Sex & $\begin{array}{l}\text { Agel } \\
\text { mean age }\end{array}$ & $\begin{array}{l}\text { Type of } \\
\text { perforation }\end{array}$ & Comorbidities & Presentation & Treatment \\
\hline 1. & $\begin{array}{l}\text { Marwah et } \\
\text { al. }^{5}\end{array}$ & 1 & $\mathrm{~F}$ & 65 year & Type- 3 & --- & $\begin{array}{l}\text { Pain abdomen and } \\
\text { fever } \\
\text { Anterior abdominal } \\
\text { wall abscess }\end{array}$ & $\begin{array}{l}\text { Laparotomy with } \\
\text { cholecystectomy }\end{array}$ \\
\hline 2. & $\begin{array}{l}\text { Misiakos et } \\
\text { al. }^{6}\end{array}$ & 1 & $\mathrm{~F}$ & 82 year & Type- 3 & COPD, HTN & $\begin{array}{l}\text { Anterior abd wall } \\
\text { abscess/swelling }\end{array}$ & $\begin{array}{l}\text { Transcutaneous } \\
\text { paracentesis }\end{array}$ \\
\hline 3. & $\begin{array}{l}\text { Varshney et } \\
\text { al. }^{7}\end{array}$ & 1 & $\mathrm{~F}$ & 80 year & Type- 3 & & $\begin{array}{l}\text { Pain abdomen } \\
\text { Abdominal and chest } \\
\text { wall abscess }\end{array}$ & $\begin{array}{l}\text { Cholecystectomy } \\
\text { and drainage of } \\
\text { abscess }\end{array}$ \\
\hline 4. & Sayed et al..$^{8}$ & 1 & $F$ & 85 year & Type- 3 & DM, HTN & $\begin{array}{l}\text { Abdominal swelling } \\
\text { Abdominal wall abscess }\end{array}$ & $\begin{array}{l}\text { ERCP, Stone retrieval, } \\
\text { sphincterotomy }\end{array}$ \\
\hline 5. & Illah et al. ${ }^{9}$ & 1 & $F$ & 80 year & Type- 3 & HTN & $\begin{array}{l}\text { Pain abdomen } \\
\text { Abdominal wall abscess }\end{array}$ & Cholecystectomy \\
\hline 6. & $\begin{array}{l}\text { Carragher et } \\
\text { al. }^{10}\end{array}$ & 1 & $\mathrm{~F}$ & 67 year & Type- 3 & & $\begin{array}{l}\text { Abdominal swelling } \\
\text { Abdominal wall abscess }\end{array}$ & $\begin{array}{l}\text { ERCP, Stone retrieval, } \\
\text { sphincterotomy }\end{array}$ \\
\hline 7. & Peer et al. ${ }^{11}$ & 2 & M- 2 & & Type 2-2 & & $\begin{array}{l}\text { Pain abdomen, fever } \\
\text { Liver abscess }\end{array}$ & Cholecystectomy \\
\hline 8. & Gobel et al. ${ }^{12}$ & 1 & $F$ & 30 year & Type 2 & $\begin{array}{l}\text { CKD on } \\
\text { dialysis, HTN }\end{array}$ & $\begin{array}{l}\text { Fever, pain abdomen } \\
\text { Liver abscess }\end{array}$ & $\begin{array}{l}\text { Laparotomy with } \\
\text { cholecystectomy }\end{array}$ \\
\hline 9. & Yagnik $^{13}$ & 1 & $\mathrm{~F}$ & 45 year & Type 1 & & Peritonitis & $\begin{array}{l}\text { Laparotomy with } \\
\text { cholecystectomy }\end{array}$ \\
\hline 10. & $\begin{array}{l}\text { Goel and } \\
\text { Ganguly }\end{array}$ & 1 & M & 14 year & Type 1 & & Pain abdomen, fever & $\begin{array}{l}\text { Laparotomy with } \\
\text { cholecystectomy }\end{array}$ \\
\hline 11. & Kim et al. ${ }^{15}$ & 1 & $\mathrm{~F}$ & 70 year & Type 1 & DM & Pain abdomen, fever & Cholecystectomy \\
\hline 12. & Alvi et al. ${ }^{16}$ & 1 & $M$ & 51 year & Type 1 & & Pain abdomen & Cholecystectomy \\
\hline 13. & Khan et al. ${ }^{17}$ & 1 & $\mathrm{~F}$ & 70 year & Type 2 & & Pain abdomen, Fever & Cholecystectomy \\
\hline 14. & $\begin{array}{l}\text { Chiapponi et } \\
\text { al. }^{18}\end{array}$ & 1 & M & 49 year & Type 1 & $\begin{array}{l}\text { Alcoholic } \\
\text { liver cirrhosis }\end{array}$ & $\begin{array}{l}\text { Pain abdomen, fever, } \\
\text { vomiting }\end{array}$ & $\begin{array}{l}\text { Laparotomy with } \\
\text { cholecystectomy }\end{array}$ \\
\hline 15. & $\begin{array}{l}\text { Jethwani et } \\
\text { al. }^{19}\end{array}$ & 2 & $M-2$ & $\begin{array}{l}70 \text { year } \\
58 \text { year }\end{array}$ & Type 1-2 & & Pain abdomen, fever & $\begin{array}{l}\text { Cholecystectomy } \\
\text { Cholecystostomy }\end{array}$ \\
\hline 16. & Arora et al. ${ }^{20}$ & 2 & $\begin{array}{l}M \\
F\end{array}$ & $\begin{array}{l}45 \text { year } \\
45 \text { year }\end{array}$ & Type 1-2 & $\begin{array}{l}\text { HTN, } \\
\text { DM, HTN, } \\
\text { COPD }\end{array}$ & Diffuse pain abdomen & $\begin{array}{l}\text { Laparotomy with } \\
\text { cholecystectomy }\end{array}$ \\
\hline 17. & $\begin{array}{l}\text { Karkera et } \\
\text { al. }^{21}\end{array}$ & 2 & $M-2$ & 11 year & Type 1-2 & & Pain abdomen & Cholecystectomy \\
\hline 18. & Konno et al. ${ }^{22}$ & 2 & $M-2$ & $\begin{array}{l}60 \text { year } \\
57 \text { year }\end{array}$ & Type 2 - 2 & DM,HTN & Pain abdomen & Cholecystectomy \\
\hline 19. & Jain et al. ${ }^{23}$ & 14 & $\begin{array}{l}M-4 \\
F-10\end{array}$ & $\begin{array}{l}\text { Mean-65 } \\
\text { year }\end{array}$ & $\begin{array}{l}\text { Type } 1-6 \\
\text { Type 2-8 } \\
\text { Type 3-0 }\end{array}$ & $\begin{array}{l}\text { DM, HTN, } \\
\text { COPD }\end{array}$ & $\begin{array}{l}\text { Pain abdomen, fever, } \\
\text { vomiting }\end{array}$ & $\begin{array}{l}\text { Cholecystectomy- } 9 \\
\text { Drainage- } 5\end{array}$ \\
\hline 20. & Derici et al. ${ }^{24}$ & 16 & $\begin{array}{l}M-10 \\
F-6\end{array}$ & $\begin{array}{l}69 \text { year } \\
\text { mean }\end{array}$ & $\begin{array}{l}\text { Type } 1-7 \\
\text { Type } 2-7 \\
\text { Type 3-2 }\end{array}$ & $\begin{array}{l}\text { DM, HTN, } \\
\text { COPD }\end{array}$ & $\begin{array}{l}\text { Pain abdomen, fever, } \\
\text { vomiting }\end{array}$ & Cholecystectomy \\
\hline 21. & Morris et al. ${ }^{25}$ & 17 & $\begin{array}{l}M-7 \\
F-10\end{array}$ & $\begin{array}{l}48 \text { year } \\
\text { mean }\end{array}$ & $\begin{array}{l}\text { Type } 1-1 \\
\text { Type } 2-14 \\
\text { Type } 3-2\end{array}$ & $\mathrm{DM}, \mathrm{HTN}$ & $\begin{array}{l}\text { Pain abdomen, fever, } \\
\text { vomiting }\end{array}$ & Cholecystectomy \\
\hline 22. & $\begin{array}{l}\text { Nandyala et } \\
\text { al. }^{26}\end{array}$ & 18 & $\begin{array}{l}M-11 \\
F-7\end{array}$ & + & $\begin{array}{l}\text { Type } 1-15 \\
\text { Type } 2-3 \\
\text { Type } 3-0\end{array}$ & DM, HTN & Pain abdomen, fever & $\begin{array}{l}\text { 3-Cholecystectomy } \\
\text { 11-Partial } \\
\text { Cholecystectomy } \\
\text { 4-Cholecystostomy }\end{array}$ \\
\hline 23. & Date et al. ${ }^{27}$ & 19 & $\begin{array}{l}M-10 \\
F-9\end{array}$ & $\begin{array}{l}71 \text { year } \\
\text { mean }\end{array}$ & $\begin{array}{l}\text { Type } 1-9 \\
\text { Type 2-9 } \\
\text { Type 3-1 }\end{array}$ & $\begin{array}{l}\text { DM, HTN, } \\
\text { COPD }\end{array}$ & $\begin{array}{l}\text { Pain abdomen, fever, } \\
\text { vomiting }\end{array}$ & Cholecystectomy \\
\hline
\end{tabular}


Gallbladder Perforation: A Prospective Study of Its Divergent Appearance and Management

\begin{tabular}{|c|c|c|c|c|c|c|c|c|}
\hline $\begin{array}{l}\text { S. } \\
\text { No }\end{array}$ & Study & $\begin{array}{l}\text { No. of } \\
\text { cases }\end{array}$ & Sex & $\begin{array}{l}\text { Agel } \\
\text { mean age }\end{array}$ & $\begin{array}{l}\text { Type of } \\
\text { perforation }\end{array}$ & Comorbidities & Presentation & Treatment \\
\hline 24. & $\begin{array}{l}\text { Gunasekaran } \\
\text { et al. }{ }^{28}\end{array}$ & 32 & $\begin{array}{l}M-13 \\
F-19\end{array}$ & $\begin{array}{l}56 \text { year } \\
\text { mean }\end{array}$ & $\begin{array}{l}\text { Type } 1-14 \\
\text { Type 2-12 } \\
\text { Type 3-6 }\end{array}$ & DM, HTN & $\begin{array}{l}\text { Pain abdomen, fever, } \\
\text { vomiting }\end{array}$ & $\begin{array}{l}\text { 23-Cholecystectomy } \\
\text { 5-Drainage } \\
\text { followed by delayed } \\
\text { cholecystectomy } \\
\text { 2-Cholecystostomy }\end{array}$ \\
\hline 25. & $\begin{array}{l}\text { Ergul and } \\
\text { Gozetlik }^{29}\end{array}$ & 37 & $\begin{array}{l}M-20 \\
F-17\end{array}$ & $\begin{array}{l}64 \text { year } \\
\text { mean }\end{array}$ & $\begin{array}{l}\text { Type } 1-12 \\
\text { Type } 2-21 \\
\text { Type } 3-4\end{array}$ & $\begin{array}{l}\text { DM, HTN, } \\
\text { COPD }\end{array}$ & $\begin{array}{l}\text { Pain abdomen, fever, } \\
\text { vomiting }\end{array}$ & Cholecystectomy \\
\hline 26. & Present study & 16 & $\begin{array}{l}M-10 \\
F-6\end{array}$ & $\begin{array}{l}45.5 \text { year } \\
\text { mean }\end{array}$ & $\begin{array}{l}\text { Type } 1-5 \\
\text { Type } 2-7 \\
\text { Type } 3-4\end{array}$ & DM, HTN & Pain abdomen, fever & $\begin{array}{l}\text { Cholecystectomy } \\
6 \text {-Emergency } \\
\text { 10-Elective }\end{array}$ \\
\hline
\end{tabular}

\section{Discussion}

GBP can be traumatic, iatrogenic, or idiopathic. Infections, malignancy, trauma, drugs (e.g., corticosteroids) and systemic diseases such as diabetes mellitus and atherosclerotic heart disease are common predisposing factors. ${ }^{17} \mathrm{GBP}$ is well-known, although unusual complication, in enteric fever. ${ }^{30}$

The review of literature done by our reports of 176 cases of GBP. Out of this type 1 is 75 (42.6\%) cases, type 2-80 (45.5\%) and type 3 $-21(11.9 \%)$ cases. In our series also most cases were of type 2 GBP followed by type 1 and type 3, respectively. The male to female ratio in these studies is comparable, and there is no explained dominance of one over the other gender. The age group commonly affected is as seen in our review and our series is old age group, i.e., above 45 years age group. But, it has also been seen in young age and pediatric age group. ${ }^{10,16}$

The mechanism of three types of perforation can be explained by the following mechanisms:

When the gallbladder is perforated at the fundus, it results in generalized peritonitis (type 1). If the perforation site is other than the fundus, it is easily sealed by the omentum or the intestines and the condition remains limited to the right hypochondrium with the formation of a plastrone and pericholecystic fluid or abscess (type 2). The fistulous tract forms from the gradual erosion of the chronically inflamed and densely adherent wall of the gallbladder and stomach. The other etiological factors are peptic ulcer, iatrogenic/trauma, and malignancy. 31,32

In atypical presentation like abdominal wall abscess or liver abscess- the process of gallbladder perforation and abscess formation starts with a stone obstructing the cystic duct. It causes a rise in pressure in the gallbladder leading to ischemic necrosis and perforation in the region of the fundus. The inflammation becomes walled off and localized pericholecystic abscess forms. The abscess may resolve, perforate into an adjacent viscus or penetrate the abdominal wall leading to parietal wall swelling. This stage of parietal wall abscess is often missed and patients present with cholecystocutaneous fistula due to external rupture of the abscess. ${ }^{9,33}$

The patients of GBP present commonly with pain abdomen, fever, and vomiting. These features are commonly shared by different abdominal conditions (cholecystitis, pancreatitis, cholangitis, GBP, etc.); hence, it is difficult to diagnose this condition at once. Radiological confirmation of the diagnosis is required, especially in cases of type II and III perforation. The atypical presentations of GBP like abdominal wall abscess as in our series and liver abscess has been reported in the literature ${ }^{5-12}$ which can perplex the clinician due to its unusual presentation.
In the guidelines published by the Surgical Infection Society of North America (SIS) and Infectious Disease Society of America (IDSA), antimicrobial therapy for secondary peritonitis should include an agent or a combination of agents with activity against both aerobic and anaerobic bacteria. ${ }^{34-36}$ The antimicrobial of choice should be against both gram-negative bacteria (e.g., E. coli) and anaerobic bacteria (e.g., B. fragilis). Either single-drug therapy with a broad-spectrum cephalosporin, or beta-lactam/ betalactamase inhibitor combination, or combination therapy with agents against aerobes and anaerobes, have proven effectiveness in treating community-acquired intra-abdominal infection of mild-to-moderate severity. The Surviving Sepsis Campaign (SSC) recommended that intravenous antibiotics should be started during the first 6 hours from onset of presentation to reduce mortality associated with severe sepsis.

\section{Conclusion}

GBP though a rare complication of cholecystitis with high morbidity and mortality, has no pathognomic features and is often misdiagnosed or late diagnosed owing to its similarity to other abdominal conditions in early phases. Also, the various modes of its presentation may perplex the clinician. The early assessment of the situation is required which requires experience and expertise of the surgeon. An early administration of antibiotics and surgical treatment may decrease overall morbidity and mortality associated with intrabdominal infection. Nowadays, the majority of cases can be managed with improved diagnostic means and therapeutic modalities (endoscopic, laparoscopic, endostaplers).

\section{References}

1. Simmons TC, Miller $C$, et al. Spontaneous gallbladder perforation. Am Surg 1989;55:311-313.

2. Sherlock S, Dooley J. Gallstones and inflammatory gallbladder diseases. In Sherlock S, Dooley J, eds. Diseases of the liver andbiliary system. London: Blackwell Scientific, 1997:593-624.

3. Stransberg SM, Clavien PA. Acute calculous cholecystitis. In: Haubrich W, Schaffner F, eds. Gastroenterology. Philadelphia: WB Saunders 1995:2635-2664.

4. Niemeier OW. Acute free perforation of the gall bladder. Ann surg 1934;99(6):922-924.

5. Marwah S, Godara R, et al. Spontaneous gallbladder perforation presenting as abdominal wall abscess. Int J Surg 2006;12:2.

6. Misiakos E, Tzepi I, et al. Gallbaldder perforation causing a subcutaneous abscess. Int J Surg Case Rep 2014;5(12):1088-1090.

7. Varshney P, Dhaked SK, et al. Gallbladder perforation presenting as abdominal and chest wall abscess. JCR 2014;4:1-3. 
8. Sayed L, Sangal S, et al. Spontaneous cholecystocutaneous fistula: a rare presentation of gallstones. J Surg Case Rep 2010;5:5.

9. Illah $\mathrm{OH}$. A large abdominal wall abscess as a presentation of gallstone disease in an elderly woman. BMJ Case Rep 2013.

10. Carragher AM, Jackson PR, et al. Subcutaneous herniation of gallbladder with spontaneous cholecystocutaneous fistula. Clin Radiol 1990;42:283-284.

11. Peer A, Witz E, et al. Intrahepatic abscess due to gallbladder perforation. Abdom Imaging 1995;20(5):452-455.

12. Göbel T, Kubitz R, et al. Intrahepatic type II gall bladder perforation by a gall stone in a CAPD patient. Eur J Med Res 2011;16(5):213-216.

13. Yagnik VD. Type-1 gall bladder perforation: Rare complication of cholelithiasis. Saudi J Gastroenterol 2011;17:84.

14. Goel A, Ganguly PK. Gallbladder perforation: A case report and review of the literature. Saudi J Gastroenterol 2004;10:155-156.

15. Kim HJ, Park SJ, et al. A case of spontaneous gallbladder perforation. Korean J Intern Med 2004;19(2):128-131.

16. Alvi AR, Ajmal $S$, et al. Acute free perforation of gall bladder encountered at initial presentation in a 51 years old man: a case report. Cases J 2009;2:166.

17. Khan SA, Gulfam, et al. Gallbladder perforation: a rare complication of acute cholecystitis. J Pak Med Assoc 2010;60:228-229.

18. Chiapponi C, Wirth $S$, et al. Acute gallbladder perforation with gallstones spillage in a cirrhotic patient. World J Emerg Surg 2010,5:11

19. Jethwani U, Singh G, et al. Gall bladder perforation: report of two cases. OA Case Reports 2013;2(5):50.

20. Arora L, Mir MA, et al. Case series of spontaneous gall bladder perforation and review of literature. Int Surg J 2015;2:406-410.

21. Karkera PJ, Sandlas G, et al. Acute acalculous cholecystitis causing gall bladder perforation in children. J Indian Assoc Pediatr Surg 2010;15:139-141.

22. Konno K, Ishida H, et al. Gallbladder perforation: color Doppler findings. Abdom Imaging 2002;27:47-50

23. Jain $\mathrm{S}$, Kolla $\mathrm{V}$, et al. Study of clinical profile and outcome of gall bladder perforations at a tertiary care centre from central India. Int Surg J 2017;4:252-256.
24. Derici $\mathrm{H}$, Kara $\mathrm{C}$, et al. Diagnosis and treatment of gallbladder perforation. World J Gastroenterol 2006;12(48):7832-7836.

25. Morris BS, Balpande PR, et al, The CT appearances of gallbladder perforation. Br. J. Radiol. 2007;80:898-901.

26. Nandyala VNR, Pallam P, et al. Gall bladder perforation-is it still a diagnostic dilemma: a retrospective study. Int Surg J 2016;3: 609-613.

27. Date RS, Thrumurthy SG, et al. Gallbladder perforation: case series and systematic review. Int J Surg 2012;10(2):63-68.

28. Gunasekaran G, Naik D, et al. Gallbladder perforation: a single center experience of 32 cases. Korean J Hepatobiliary Pancreat Surg 2015;19:6-10

29. Ergul E, Gozetlik EO. Perforation of gallbladder. Bratislavskelekarskelisty 2008;109(5):210-214.

30. Pandey A, Gangopadhyay AN, et al. Gall bladder perforation as a complication of typhoid fever. Saudi J Gastroenterol 2008;14: 213.

31. Mathew G, Bhimji SS. Fistula, cholecystocutaneous. Treasure Island, FL: Stat Pearls Publishing; 2017 Jun.

32. Micu BV, Andercou OA, et al. Spontaneous cholecystocutaneous fistula as a primary manifestation of gallbladder adenocarcinoma associated with gallbladder lithiasis - case report. Rom J Morphol Embryol 2017;58(2):575-583.

33. Roslyn JJ, Thompson JE Jr, et al. Risk factors for gallbladder perforation. Am J Gastroenterol 1987;82:636-640.

34. Kim PN, Lee KS, et al. Gallbladder perforation: comparison of US findings with CT. Abdom Imaging 1994;19:239-242.

35. Mazuski JE, Sawyer RG, et al. Therapeutic Agents Committee of the Surgical Infections Society. The Surgical Infection Society guidelines on antimicrobial therapy for intra-abdominal infections: an executive summary. Surg Infect (Larchmt) 2002;3:161-173.

36. Solomkin JS, Mazuski JE, et al. Infectious Diseases Society of America. Guidelines for the selection of anti-infective agents for complicated intra-abdominal infections. Clin Infect Dis 2003;37: 997-1005. 